\title{
HUTANG JANGKA PENDEK BAGI PERUSAHAAN TERTUTUP DI JABODETABEK
}

\author{
Vina Christina Nugroho \\ Manajemen, Universitas Pelita Harapan \\ Alamat surel: vina.nugroho@uph.edu
}

\begin{abstract}
The purpose of this study is to determine what factors affect the Short-term Debt in small private unlisted firms. In addition, this study also examine the effect on the condition of the company that is experiencing financial pressure or in a stable condition against their short-term debts.Data used in this study is the financial statements of small companies (sales $<R p 150$ billion in a year). Where there are 99 small private unlisted firms studied in Jabodetabek. The financial statements of the company that occurred is the period of 2008 - 2011. The results of the study indicate the existence of differences in factors that affect short-term debt on two different company conditions. The previous Short Term Liabilities variable and the Growth variable significantly affectShort Term Debt Period in the company under financial distress condition. Conversely, on company in a stable condition or Non-Financial Distress, Previous Short Term Liabilities Variables, Growth, and sizes siginificantly affect short-term debt current period.

Keywords: Short-Term Debt, Private Firm
\end{abstract}

\begin{abstract}
Abstrak
Tujuan dari penelitian ini adalah untuk mengetahui faktor apa saja yang memengaruhi hutang jangka pendek pada perusahaan kecil yang tidak IPO. Penelitian ini juga mendeteksi apakah ada pengaruh kondisi perusahaan yang sedang mengalami tekanan finansial ataupun dalam kondisi stabil terhadap hutang jangka pendek pada perusahaan kecil tersebut.Data yang digunakan dalam penelitian ini adalah laporan keuangan perusahaan kecil (penjualan < Rp 150 Milyar dalam setahun). Terdapat 99 perusahaan kecil yang tidak IPO yang berlokasi di Jabodetabek. Laporan keuangan perusahaan yang didapat adalah periode tahun 2008 - 2011. Hasil dari penelitian menunjukan bahwa terdapat perbedaan faktor-faktor yang memengaruhi hutang jangka pendek pada dua kondisi perusahaan yang berbeda. Pada kondisi perusahaan dibawah tekanan finansial, peubah hutang jangka pendek periode sebelumnya dan peubah tingkat pertumbuhan (Growth) memiliki pengaruh signifikan terhadap hutang jangka pendek periode saat ini. Pada kondisi perusahaan yang stabil atau Non Financial Distress, peubah hutang jangka pendek periode sebelumnya, peubah tingkat pertumbuhan (Growth), dan peubah ukuran perusahaan (Size) berpengaruh signifikan terhadap hutang jangka pendek periode saat ini.
\end{abstract}

Kata Kunci: Hutang Jangka Pendek, Perusahaan Tertutup

\section{PENDAHULUAN}

\section{Latar Belakang}

Penelitian ini secara lebih spesifik ingin meneliti faktor-faktor yang memengaruhi hutang jangka pendek perusahaan kecil pada kondisi di bawah tekanan finansial maupun pada kondisi stabil di Indonesia. Peneliti memilih perusahaan kecil sebagai subyek penelitian dikarenakan masih jarangnya penelitian di Indonesia terhadap perilaku-perilaku perusahaan kecil yang tidak IPO di pasar ekonomi Indonesia. Menurut Ang (Storey, 2000, 574), paradigma baru dari perusahaan kecil adalah mengidentifikasi fitur-fitur perusahaan kecil tersebut yang tentu berbeda dengan fiturfitur pada perusahaan besar. Karakter unik dari perusahaan kecil ini tentu akan menghasilkan masalah finansial yang berbeda dan menghasilkan keputusan finansial, tipe kesepakatan, institusi dan pratek yang dikembangkan yang berbeda pula.

Perusahaan kecil berkontribusi dalam menciptakan lapangan pekerjaan pada suatu negara. Ketika suatu perusahaan kecil hendak mengambil keputusan yang 
berkaitan dengan struktur keuangan perusahaan tersebut, faktor yang memengaruhi tidak hanya hutang jangka panjang semata, tetapi hutang jangka pendek juga sangat memengaruhi. Dalam mempelajari kondisi suatu perusahaan kecil, terlihat bahwa perusahaan kecil mengalami kesulitan untuk mendapatkan hutang jangka panjang, karena bank akan cenderung melihat perusahaan kecil memiliki resiko gagal bayar yang relatif besar, sehingga, bank akan lebih memilih untuk melakukan pembiayaan berupa hutang jangka pendek. Padangan lain menurut Bigelli et al. (2014 : 2) perusahaan tertutup umumnya memiliki proporsi hutang jangka pendek yang lebih besar dari pada hutang total. Perusahaan tertutup di negara yang memiliki proteksi terhadap kreditur yang rendah memiliki karakter penggunaan dana internal yang lebih besar, lebih banyak hutang jangka pendek dan mengalami banyak kesulitan dalam mendanai aset yang tidak berwujud.

Penelitian dari Bigelli et al. (2014 : 2), perusahaan tertutup umumnya memiliki perilaku finansial yang konservatif dimana mereka cenderung memiliki simpanan kas yang lebih besar dan kebijakan hutang yang rendah. Penelitian ini juga bertujuan untuk mengetahui efek dari tekanan finansial terhadap keputusan struktur finansial pada perusahaan-perusahaan kecil tersebut. Perusahaan kecil yang umumnya memiliki perilaku yang konservatif akan berubah menjadi tidak konservatif ketika mereka mengalami penurunan arus kas (Cash Flow). Apa yang akan terjadi ketika perusahaan menghadapi situasi yang dimana tidak mampu membayar hutang? apakah perusahaan-perusahaan kecil yang berada dalam tekanan finansial akan berperilaku sesuai dengan teori finansial?

Berdasarkan Pengetahuan yang telah diberikan, makalah ini berkontribusi pada literatur struktur permodalan dalam tiga cara, yaitu : (1) Fokus pada sektor usaha kecil dan kemampuan penyesuaian terhadap rasio target hutang (2) Fokus pada perbedaan-perbedaan yang akan menentukan keputusan pemilihan hutang jangka pendek dikarenakan adanya beberapa faktor yang ditunjukan oleh teori struktur finansial yang akan memberikan implikasi yang berbeda untuk kondisi yang berbeda pula. (3) Membentuk skema klasifikasi, untuk menentukan perusahaan-perusahaan yang mengalami tekanan finasial dan keputusan struktur finansial apa yang diharapkan untuk diambil.(4) Fokus kepada faktor-faktor penentu keputusan struktur finansial pada perusahaan-perusahaan kecil.

Untuk mencapai cara tersebut, model yang digunakan adalah Partial Adjustment Model dimana tingkat target hutang dari perusahaan ditentukan oleh faktor-faktor yang memengaruhi struktur finansial seperti hutang jangka pendek periode sebelumnya (STDt-1), aset yang terjaminkan (Colateralisable Asset), tingkat pertumbuhan (Growth), arus kas (Cash Flow) dan ukuran perusahaan (Size).

\section{TINJAUAN PUSTAKA}

\section{Dasar Teori \& Pengembangan Hipotesis}

Tekanan finansial adalah suatu situasi yang bisa membawa dampak negatif dan membahayakan kelangsungan struktur keuangan pada perusahaan. Asumsi ini didukung oleh Beaver (Pindado et al, 2006 : 382), yang menyatakan tekanan finansial didefinisikan sebagai suatu situasi dimana perusahaan tidak bisa menyelesaikan kewajiban finansial yang dimiliki ketika jatuh tempo.

Pada penelitian kali ini, untuk membedakan perusahaan yang sedang mengalami tekanan finansial dan yang tidak sedang mengalami tekanan finansial dapat dibedakan dengan melihat nilai EBIT dan biaya finansial. Asumsi ini diambil dari penelitian sebelumnya yang dilakukan oleh Pindado, Rodrigues dan la torre (2006) yang menyatakan perusaahan dikatakan berada di bawah tekanan finansial apabila EBIT < biaya finansial dan perusahaan dikatakan berada di bawah kondisi stabil jika EBIT > biaya finansial. Biaya finansial dalam penelitian ini didapat dari nilai atau jumlah bunga hutang yang harus dibayarkan oleh setiap perusahaan setiap tahunnya dimana salah satu jenis biaya finansial tetap yang dapat ditemukan dalam laporan keuangan perusahaan adalah bunga hutang (Gitman, 2006). 


\section{Hutang jangka pendek}

Penelitian ini lebih menekankan pada hutang jangka pendek sebagai peubah gayut. Hal ini mengacu pada pernyataan Bigelli et al. (2014) yang menyatakan karakteristik dari perusahaan tertutup adalah memiliki rasio hutang yang tinggi dan proporsi hutang jangka pendek yang lebih besar terhadap hutang total .

HI : Kecepatan penyesuaian hutang periode sebelumnya terhadap hutang para periode saat ini perusahaan dalam kondisi stabil lebih besar dibandingkan dengan perusahaan yang berada di bawah tekanan finansial.

H2 : Hutang jangka pendek periode sebelumnya berpengaruh postif terhadap hutang jangka pendek periode saat ini pada perusahaan stabil maupun perusahaan berada di bawah tekanan finansial.

\section{Aset yang dijaminkan}

Pada umumnya, lembaga keuangan yang memberikan pinjaman kepada perusahaan kecil meminta adanya jaminan yang memiliki nilai likuidasi yang lebih tinggi dari pada hutang perusahaan tersebut guna menjamin dana pinjaman jangka panjang yang diajukan. Dalam pengajuan hutang jangka pendek, jaminan dapat berupa proporsi dari aset total yang direpresentasikan melalui piutang dan inventori.

Aset yang berwujud akan lebih mudah untuk dijaminkan dan akan menghadapi pengurangan nilai ketika perusahaan tersebut mengalami tekanan finansial. Perspektif terori trade off, aset yang berwujud memiliki efek yang penting dalam biaya tekanan finansial. Pemegang saham akan susah untuk mengganti aset yang memiliki resiko yang tinggi dengan aset yang memiliki resiko yang rendah.Teori statis Trade off memprediksi pengaruh positif antara hutang dan aset berwujud menurut Frank \& Goyal (Espen Eckbo, 2008). Perusahaan akan mengalami kesulitan dalam pembiayaan dengan menggunakan hutang apabila tidak ada aset yang dijadikan jaminan dari hutang tersebut. (Bigelli et al., 2014)

H3 : Jaminan (Collateral) berpengaruh positif terhadap hutang jangka pendek pada perusahaan stabil maupun perusahan berada di bawah tekanan finansial.

\section{Tingkat Pertumbuhan}

Pindado, Rodrigues dan La Torre (2006, 381) berpendapat ketika tingkat pertumbuhan perusahaan turut meningkatkan kebutuhan akan dana, maka akan memberikan pengaruh positif terhadap hutang. Keterhubungan antara tingkat pertumbuhan (Growth) dan hutang berdasarkan prediksi dari Static Trade Off Theory adalah adanya pengaruh negatif antara kedua peubah tersebut. Misal, masalah investasi yang rendah lebih memengaruhi pertumbuhan perusahaan. Agency Cost of free cash flow kurang berpengaruh terhadap perusahaan yang sedang bertumbuh dan ini juga mengacu kepada prediksi bahwa perusahaan yang sedang bertumbuh seharusnya memiliki hutang yang sedikit.

Teori Pecking Order memberikan prediksi bahwa perusaahaan yang sedang profitable dan melakukan banyak investasi seharusnya memiliki hutang yang semakin banyak. Berdasarkan teori pecking order, hutangdan tingkat pertumbuhan (growth) memiliki korelasi positif (Frank \& Goyal (Espen Eckbo, 2008)).

H4 : Tingkat pertumbuhan berpengaruh positif terhadap hutang jangka pendek pada perusahaan stabil maupun perusahaan berada di bawah tekanan finansial.

\section{Dana Internal Perusahaan}

Berdasarkan teori Pecking Order, perusahaan-perusahaan mengembangkan alternatif pilihan seperti, dana internal sebagai pilihan utama, mengajukan hutang ketika dana internal tidak mencukupi dan kebutuhan akan modal baru sebagai pilihan terakhir dalam memilih alternatif keuangan perusahaan. Pandangan ini didukung oleh Bigelli et al (2014 : 3) yang memprediksi adanya pengaruh positif antara arus kas terhadap kemungkinan perusahaan menggunakan pembiayaan secara konservatif. Ketika perusahaan tersebut memiliki arus kas yang negatif, maka akan ada kebutuhan yang besar akan dana eksternal. 
Tidak ada prediksi akurat yang dapat dibuat untuk mengetahui keterhubungan antara dana internal dengan pembiayaan hutang pada perusahaan yang sedang mengalami tekanan finansial. Dalam menguji hipotesis ini, Miguel (Pindado et al., 2006 : 382) menggunakan arus kas untuk mewakili dana internal perusahaan karena dianggap sebagai peubah yang paling akurat selama mencerminkan pendapatan perusahaan ditambah pengurangan bukan tunai (non - cash) dari pendapatan tersebut guna mengetahui nilai dana internal dari setiap perusahaan yang nantinya akan diregresikan.

H5 :arus kas berpengaruh negatif terhadap hutang jangka pendek pada perusahaan stabil dan perusahaan pada kondisi di bawah tekanan finansial.

\section{Ukuran Perusahaan / Size}

Teori Statis Trade Off, memprediksikan bahwa perusahaan besar memiliki hutang yang lebih banyak, karena kreditor dan perusahaan itu sendiri diasumsikan memiliki risiko gagal bayar yang rendah. Teori Trade Off memprediksikan bahwa hutang dan ukuran perusahaan seharusnya memiliki keterhubungan yang positif.

$$
\text { Teori Pecking Order }
$$

memprediksikan adanya keterhubungan negatif antara hutang dan ukuran perusahaan. Argumen ini didasarkan pada pandangan bahwa perusahaan besar memiliki aset yang lebih banyak, sehingga ketika perusahaan besar menghadapi adverse selection, perusahaan besar tersebut akan lebih mudah untuk mengeluarkan ekuitas mereka dari pada menggunakan hutang (Frank \& Goyal (Espen Eckbo, 2008)). Hal ini juga didukung oleh pandangan dari Bigeli et al., (2014 : 3) yang menyatakan bahwa ukuran perusahaan memiliki keterhubungan yang negatif dengan hambatan keuangan pada perusahaan dan adanya kecenderungan perusahaan tersebut untuk mengikuti keputusan keuangan yang konservatif.

H 6 : Ukuran perusahaan berpengaruh negatif terhadap hutang jangka pendek pada perusahaan yang berada pada kondisi di bawah tekanan finansial dan berpengaruh positif pada perusahaan stabil.

\section{METODE}

\section{Jenis data dan Sumber}

Peneliti mendapatkan data laporan laba rugi 99 perusahaan kecil yang tidak IPO atau perusahaan tertutup di Indonesia dari satu lembaga keuangan swasta yang berpusat di Jakarta dan enggan untuk disebutkan namanya. Data yang didapat berupa data sekunder. Sumber dari data sekunder juga terbagi menjadi dua jenis, yaitu sumber data internal dan sumber data eksternal. Penelitian ini menggunakan sumber data internal dikarenakan sumber data tersebut berasal dari laporan keuangan 99 perusahaan-perusahaan kecil di Indonesia dengan penjualan tidak lebih dari Rp 150.000.000.000,- pertahun dan tidak melakukan Initial Public Offering. Adapun laporan laba rugi yang diambil adalah laporan laba rugi empat tahun periode 2008 s.d 2011 dari setiap perusahaan. Periode waktu tersebut dipakai karena untuk melihat dampak dari fenomena krisis global di tahun 2008 pada perusahaan kecil di Jabodetabek.

\section{Teknik Analisis Data}

Peneliti menggunakan Analisis Regresi Berganda sebagai metode analis data karena memiliki tujuan untuk menguji adanya keterhubungan antara dua atau lebih peubah bebas, terhadap peubah gayut.

\section{Model Empiris}

$$
\begin{aligned}
& \text { Struktur Model dari Debt } \\
& \text { Adjutsment Model } \\
& \mathbf{D}_{\mathbf{i t}}-\mathbf{D}_{\mathbf{i t}-\mathbf{1}}=\boldsymbol{\alpha}\left(\mathbf{D}_{\text {it }}^{*}-\mathbf{D}_{\mathbf{i t}-\mathbf{1}}\right) \mathbf{0}<\boldsymbol{\alpha}<\mathbf{1}
\end{aligned}
$$

Tingkat hutang perusahaan saat ini dapat dilihat dari model:

$$
D_{i t}=\alpha D^{*}{ }_{i t}+(1-\alpha) D_{i t-1}
$$

Target hutang dapatdiketahui dari :

$$
\begin{aligned}
& D^{*}{ }_{i t}=\beta 1+\beta 2\left(\frac{\text { COLLAS }}{T A}\right)_{i t}+\beta 5 \text { Growth }_{i t}+\beta 6 \\
& \left(\frac{C F}{T A}\right)_{i t}+\beta 7 \operatorname{SIZE~}_{i t}+\varepsilon_{i t}
\end{aligned}
$$


Persamaan (2) dan (3) digabungkan, sehingga terbentuklah Partial Adjustment Model :

$$
\begin{aligned}
& D_{i t}=\alpha \beta 1+(1-\alpha) D_{i t-1}+\alpha \beta 2\left(\frac{\text { COLLAS }}{T A}\right)_{i t}+ \\
& \alpha \beta 3 \text { GROWTH }+\alpha \beta 4\left(\frac{C F}{T A}\right)_{i t}+\alpha \beta 5 \text { SIZE }_{i t}+
\end{aligned}
$$$$
\varepsilon_{\text {it }}
$$

Aset yang dijaminkan (Collas), tingkat pertumbuhan (Growth) dan arus kas (CF) berperan sebagai peubah bebas yang memengaruhi pemilihan struktur permodalan pada perusahaan. Ukuran perusahaan (Size), berperan sebagai peubah kontrol.

Dalam mengklasifikasikan perusahaan yang mengalami tekanan finasial dan perusahaan yang tidak mengalami tekanan finansial, dapat menggunakan sample selection dummy variable dimana akan menghasilkan nilai satu untuk perusahaan-perusahaan yang mengalami masalah finansial pada periode pertama $(F D D)$ dan nilai nol bagi perusahaan yang tidak mengalami tekanan finansial (Non $F D D$ ). Hasil tersebut kemudian diinteraksikan dalam model (4) untuk mempelajari apakah efek dari struktur finansial perusahaan berbeda bergantung pada dua kategori yang teriidentifikasi, sehingga digunakan model :

$D_{i t}=\alpha \beta 1+\left[(1-\alpha)+\left(1-\alpha^{\prime}\right) F^{\prime} D_{i t}\right] D_{i t-1}+$ $\left(\alpha \beta 2+\beta{ }_{2}\right.$ FDD $\left._{i t}\right)\left(\frac{\text { COLLAS }}{\text { TA }}\right)_{i t}+\left(\alpha \beta 3+\beta{ }_{3}\right.$ FDD $\left._{\text {it }}\right)$ Growth $_{\text {it }}+\left(\alpha \beta 4+\beta{ }_{4}\right.$ FDD $\left._{\text {it }}\right)\left(\frac{C F}{T A}\right)_{\text {it }}$ $+\left(\alpha \beta 5+\beta{ }_{5}\right.$ FDD $\left._{i t}\right)$ Size $_{i t}+$ git

$(1-\alpha)$ dan $\left[(1-\alpha)+\left(1-\alpha^{\prime}\right)\right]$ merefleksikan efek dari rasio hutang pada periode sebelumnya baik pada perusahaan yang mengalami tekanan finansial maupun yang tidak mengalami tekanan finansial.

Dalam rangka menyempurnakan model (4) dan (5), dimasukannya peubah $\eta_{i}$ untuk mengeliminasi risiko hasil yang bias dikarenakan adanya heterogenitas. Peubah $d_{t}$ untuk mengukur efek temporal dari corresponding dummy variables, sehingga dapat mengontrol efek dari peubah makro ekonomi pada rasio hutang (Pindado, Rodrigues \& La Torre 2006 , 383).
Konsekuensinya, model (4) dan (5) ditransformasikan menjadi :

$$
\begin{aligned}
& D_{i t}=\alpha \beta 1+(1-\alpha) D_{i t-1}+\alpha \beta 2\left(\frac{\text { COLLAS }}{T A}\right)_{i t}+ \\
& \alpha \beta 3 \text { GROWTH }+\alpha \beta 4\left(\frac{\text { CF }}{\text { TA }}\right)_{\text {it }}+\alpha \beta 5 \text { SIZE }_{\text {it }}+ \\
& d_{t}+\eta_{\mathrm{i}}+v_{i t}
\end{aligned}
$$

Pada penelitian kali ini, akan dilakukan penelitian dengan dua peubah gayut pada dua kondisi perusahaan yang sedang mengalami tekanan finansial (FDD) dan perusahaan yang tidak sedang mengalami tekanan finansial (Non FDD). Sehingga akan ada dua model yang di estimasi dengan rincian sebagai berikut:

Hutang jangka pendek sebagai peubah gayut

- STD $_{\text {it }}=\alpha \beta 1+(1-\alpha) D_{\text {it-1 }}+\alpha \beta 2($ $\left.\frac{\text { COLLAS }}{\text { TA }}\right)_{\text {it }}+\alpha \beta 3$ GROWTH $+\alpha \beta 4$ $\left(\frac{\mathrm{CF}}{\mathrm{TA}}\right)_{\mathrm{it}}+\alpha \beta 5 \mathrm{SIZE}_{\mathrm{it}}+d_{t}+\eta_{\mathrm{i}}+v_{i t}$

- $\mathrm{STD}_{\mathrm{it}}=\alpha \beta 1+\left[(1-\alpha)+\left(1-\alpha^{\prime}\right) \mathrm{FDD}_{\text {it }}\right.$ ] $D_{\text {it-1 }}+\left(\alpha \beta 2+\beta_{2}{ }_{2}\right.$ FDD $\left._{\text {it }}\right)\left(\frac{\text { COLLAS }}{T A}\right.$ )$_{\text {it }}+\left(\alpha \beta 3+\beta{ }_{3}\right.$ FDD $\left._{\text {it }}\right)$ Growth $_{\text {it }}+$ $\left(\alpha \beta 4+\beta{ }_{4}\right.$ FDD $\left._{\mathrm{it}}\right)\left(\frac{\mathrm{CF}}{\mathrm{TA}}\right)_{\mathrm{it}}+(\alpha \beta 5+$ $\beta_{5}{ }_{5}$ FDD $\left._{\text {it }}\right)$ Size $_{i t}+d_{t}+\eta_{\mathrm{i}}+v_{i t}$

\section{Uji Redundant Fixed Effect}

Uji Redundant Fixed Effect dilakukan untuk memilih antara model Common Effect dan model Fixed Effect yang diuji dengan $F$ statistik untuk membandingkan residual sum of squares (RSS) antara model Common Effect dan model Fixed Effect.

$\mathrm{H}_{0} \quad$ : model memiliki intercept yang sama (memilih model Common Effect) $\mathrm{H}_{1} \quad$ : model memiliki intercept yang berbeda (memilih model Fixed Effect) 


\section{$R^{2}$ dan Uji F}

$\mathrm{R}^{2}$ digunakan untuk mengetahui seberapa baik model regresi memiliki kecocokan dengan data. Nilai $\mathrm{R}^{2}$ harus berada di antara nol sampai dengan satu. Semakin nilai $\mathrm{R}^{2}$ mendekati satu, kecocokan model dengan data semakin baik. Jika nilai semakin mendekati nol, maka kecocokan model dengan data semakin rendah. Definisi lain dari $\mathrm{R}^{2}$ adalah seberapa baik model tersebut dapat dijelaskan (Brooks, 2008). Uji $F$ digunakan untuk menentukan siginifikansi keseluruhan regresi yang diestimasi, sekaligus menguji signifikansi dari $\mathrm{R}^{2}$.

Ho : Semua Regressor secara bersama-sama tidak dapat menjelaskan regressand

H1 : Tidak semua regressors tidak dapat menjelaskan regressand

Jika nilai $\mathrm{P}$ dari $\mathrm{F}$ Statistik lebih rendah daripada signifikan level, maka Ho ditolak (Brooks, 2008)

\section{Menguji Siginifikansi Koefisien Regresi (Uji T dan Nilai P)}

Pengujian signifikansi adalah untuk menguji apakah setiap peubah bebas memiliki pengaruh terhadap peubah gayut, baik korelasi positif maupun negatif. Di dalam pengujian signifikansi, peubah bebas tersebut dikatakan siginifikan jika nilai test statistik berada pada daerah kristis (critical region). Pengujian untuk mengetahuiapakah setiap peubah bebas memiliki pengaruh yang signifikan atau tidak, dapat digunakan aturan keputusan nilai $\mathrm{P}$.

Ho $: \beta=0$ (peubah bebas tidak memiliki pengaruh terhadap peubah gayut)

$\mathrm{H} 1: \beta \neq 0$ (peubah bebas memiliki pengaruh terhadap peubah gayut)

Tingkat signifikan level yang digunakan adalah sebesar $5 \%$ pada penelitian ini. Apabila nilai $\mathrm{p}$ lebih rendah dari pada signifikan level maka Ho ditolak. (Brooks, 2008)

\section{HASIL DAN PEMBAHASAN}

\section{Tabel Kolinearitas}

Tabel Kolinearitas digunakan untuk melihat keterhubungan timbal balik antara satu peubah dengan peubah lainnya. Nilai kolinearitas antar sesama peubah bebas diharapkan tidak lebih dari satu. Tabel 4.1 menjabarkan korelasi antar masing-masing peubah dengan peubah lainnya pada perusahaan yang sedang mengalami tekanan finansial. Tabel 4.2 menjabarkan korelasi antar masing-masing peubah dengan peubah lainnya pada perusahaan yang tidak sedang mengalami tekanan finansial. Hasil kedua tabel tersebut, nilai kolinearitas hubungan antara sesama peubah bebas tidak ada yang melebihi nilai satu atau bahkan tidak ada yang mendekati nilai satu, sehingga tidak ada masalah kolinearitas pada peubah kedua model tersebut.

Tabel 1. Tabel Kolinearitas pada perusahaan FDD

\begin{tabular}{lllllll}
\hline & STD_FDD & STD_IT & COLAS & GROWTH & CF_TA & SIZE \\
\hline STD_FDD & 1 & 0.791422 & 0.458864 & 0.164412 & 0.376203 & -0.47051 \\
STD_IT & 0.791422 & 1 & 0.468051 & -0.0068 & 0.365713 & -0.47607 \\
COLAS & 0.458864 & 0.468051 & 1 & 0.286586 & 0.086433 & -0.52658 \\
GROWTH & 0.164412 & -0.0068 & 0.286586 & 1 & 0.029415 & -0.14541 \\
CF_TA & 0.376203 & 0.365713 & 0.086433 & 0.029415 & 1 & 0.020671 \\
SIZE & -0.47051 & -0.47607 & -0.52658 & -0.14541 & 0.020671 & 1 \\
\hline Sur & & & & & & \\
\hline
\end{tabular}

Sumber : Data Proses 
Tabel 2. Tabel Kolinearitas pada perusahaan Non FDD

\begin{tabular}{lllllll}
\hline & STD_NonFdd & STD_IT & COLAS & GROWTH & CF_TA & SIZE \\
\hline STD_NONFDD & 1 & 0.876339 & 0.248767 & 0.1828 & 0.136705 & -0.11561 \\
STD_IT & 0.876339 & 1 & 0.170772 & 0.059868 & 0.203001 & -0.18591 \\
COLAS & 0.248767 & 0.170772 & 1 & 0.104123 & -0.06643 & -0.2902 \\
GROWTH & 0.1828 & 0.059868 & 0.104123 & 1 & 0.01052 & -0.01996 \\
CF_TA & 0.136705 & 0.203001 & -0.06643 & 0.01052 & 1 & -0.2982 \\
SIZE & -0.11561 & -0.18591 & -0.2902 & -0.01996 & -0.2982 & 1 \\
\hline Sun
\end{tabular}

Sumber : Data Proses

\section{Uji F}

Uji F pada kedua model, dilihat dari nilai $\mathrm{P}$ dengan tingkat signifikan level sebesar 5\%. Pada model hutang jangka pendek pada perusahaan yang mengalami tekanan finansial, peubah bebas yang memiliki pengaruh terhadap peubah gayut apabila nilai $\mathrm{p}$ dari nilai $\mathrm{F}$ statistik lebih kecil dari pada 5\%, maka Ho ditolak, dalam arti, peubah bebas berpengaruh signifikan terhadap peubah gayut. Nilai $\mathrm{P}$ dari Fstatistik peubah bebas pada hutang jangka pendek perusahaan yang mengalami tekanan finansial berada di bawah 5\% adalah peubah hutang jangka pendek periode sebelumnya (STD_IT) dan tingkat pertumbuhan (Growth). Peubah hutang jangka pendek periode sebelumnya (STD_IT) dan tingkat pertumbuhan (Growth) adalah peubah bebas yang berpengaruh signifikan terhadap peubah hutang jangka pendek (STD) pada perusahaan dengan kondisi berada di bawah tekanan finansial (FDD).

Pada model hutang jangka pendek (STD) perusahaan stabil (Non FDD), dengan tingkat signifikansi level sebesar 5\%, Nilai $P$ dari peubah bebas yang berada dibawah nilai $5 \%$ adalah peubah hutang jangka pendek periode sebelumnya (STDIT), peubah tingkat pertumbuhan (Growth) dan ukuran perusahaan (Size). Peubah bebas tersebut berpengaruh signifikan terhadap peubah gayut yaitu hutang jangka pendek (STD) pada perusahaan stabil atau tidak berada di bawah tekanan finansial (Non $F D D)$ di Indonesia.

Tabel 3. Hasil Regresi Perusahaan Non FDD

\begin{tabular}{lllll}
\hline Peubah Gayut & Peubah Ingayut & Koefisien & P.Value & Pengaruh \\
\hline STD_Non FDD & STD_IT & 0.768808 & 0.0000 & Signifikan \\
& Colas & 0.115893 & 0.0679 & Tidak Signifikan \\
& Growth & 0.035453 & 0.0000 & Signifikan \\
& CF_TA & -0.015788 & 0.8083 & Tidak Signifikan \\
& Size & 0.030879 & 0.0311 & Signifikan \\
\hline
\end{tabular}

Sumber : Data Proses

\section{Pemilihan Model Regresi}

\section{Uji Redundant Fixed Effect}

Peneliti melakukan uji redundant Fixed Effect untuk mengetahui model manakah yang lebih baik dipakai antara Fixed Effect dan Common Effect. Penelitian ini meneliti dua model yang berbeda yaitu hutang jangka pendek (STD leverage) pada perusahaan yang berada di bawah tekanan finansial $(F D D)$ dan hutang jangka pendek pada perusahaan dengan kondisi stabil (Non FDD).

Pada model hutang jangka pendek (STD) perusahaan stabil (Non FDD), telah dilakukan Uji Redundant Fixed Effect dan menghasilkan nilai chi square 0.0000 . Disimpulkan H0 ditolak , sehingga untuk model hutang jangka pendek (STD) pada perusahaan stabil (Non FDD), model Fixed Effect lebih sesuai dari pada model Common 
Effect. Lain halnya pada model hutang jangka pendek (STD) perusahaan FDD, telah dilakukan Uji Redundant Fixed Effect dan menghasilkan nilai chi square 0.2122 . Sehingga, untuk model STD pada perusahaan FDD, model Fixed Effect kurang sesuai. Oleh karena itu, dilakukan Uji Hausman.

\section{Uji Hausman}

Pada model STD leverage perusahaan

FDD dilakukan Uji Hausman untuk mengetahui pemilihan model Fixed Effect atau Random Effect. Hasil yang didapat setelah melukan Uji Spesifikasi Hausman adalah nilai probabilitas chi-square sebesar 0.5222. Dari hasil ini, bisa disimpulkan bahwa Ho pada uji spesifikasi Hausman tidak ditolak. Sehingga, model random effect lebih sesuai untuk dipilih dari pada model fixed effect.

Tabel 4. Hasil Uji Redundant Fixed Effect Perusahaan Non FDD

\begin{tabular}{ll}
\hline Effects Test & Prob. \\
\hline Cross Section Chi- & 0.0000 \\
Square & \\
\hline Sumber : Data Proses
\end{tabular}

Tabel 5. Hasil Uji Redundant Fixed Effect Perusahaan FDD

\begin{tabular}{ll}
\hline Effects Test & Prob. \\
\hline Cross Section Chi- 0.21222 \\
Square
\end{tabular}

Tabel 6. Hasil Uji Hausman Random Effect Perusahaan FDD

\begin{tabular}{llll}
\hline Effects Test & & Prob. \\
\hline Cross & Section & Chi- & 0.5222
\end{tabular}

Square

Sumber : Data Proses

\section{Hasil Uji Hipotesis}

Peubah STD_IT juga berpengaruh signifikan terhadap STD pada perusahaan stabil (Non FDD) dengan nilai $\mathrm{P}$ sebesar 0.0000 dan besarnya pengaruh sebesar 0.768808. Terdapat Speed of adjustment pada perusahaan Non FDD di Indonesia sebesar $23.1192 \%$. Hasil ini didukung oleh teori Trade off yang menyatakan adanya target dari penggunaan hutang untuk memaksimalkan nilai perusahaan.

Peubah jaminan (Colas) pada perusahaan kecil stabil (Non FDD) di Indonesia tidak berpengaruh signifikan terhadap hutang jangka pendek (STD). Ketika perusahaan yang dalam kondisi stabil, mereka tidak akan mempertimbangkan nilai collateral, karena perusahaan tersebut bisa melihat kemampuan struktur finansial dari mereka sendiri, dimana dirasa mampu mebayar hutang-hutang tersebut tanpa harus melihat nilai jaminan.

Pada perusahaan stabil(non FDD) di Indonesia, peubah tingkat pertumbuhan (growth) juga memiliki pengaruh yang signifikan terhadap hutang jangka pendek. Nilai Peubah tingkat pertumbuhan (Growth) sebesar 0.0000 dan nilai koefisien sebesar 0.035453 . Hasil ini sesuai dengan pecking order theory yang menyatakan bahwa perusahaan yang sedang bertumbuh seharusnya memiliki hutang yang lebih banyak. Sehingga, sesuai dengan Pecking order theory, Growth dan Debt Leverage memiliki hubungan yang positif. Ketika perusahaan tersebut sedang dalam masa bertumbuh ke arah yang lebih baik, umumnya baik perusahaan besar maupun perusahaan kecil akan membutuhkan bantuan dana baik dari internal maupun eksternal dalam usaha bertumbuh dan berkembang.

Peubah arus kas (CF_TA) pada perusahaan stabil di Indonesia tidak memiliki pengaruh signifikan terhadap hutang jangka pendek dan dilihat dari nilai koefisien sebesar -0.015788, menyatakan adanya korelasi negatif antara arus kas dengan hutang jangka pendek. Pada 
perusahaan kecil (Non FDD) di Indonesia yang memiliki arus kas yang cukup, mereka tidak akan melakukan pengajuan hutang jangka pendek. Perusahaan-perusahaan tersebut akan lebih memilih pembiayaan dari dana internal jika dirasa masih mencukupi.

Peubah ukuran perusahaan (Size) pada perusahaan stabil memiliki pengaruh yang signifikan terhadap hutang jangka pendek dengan nilai $\mathrm{P}$ sebesar 0.0311 dan koefisien sebesar 0.030879, dimana nilai koefisien tersebut meninterpretasikan adanya korelasi positif antara ukuran perusahaan dan hutang jangka pendek pada perusahaan Non FDD. Hasil ini didukung oleh teori Static Trade
Off yang memprediksi, semakin perusahaan tersebut bertumbuh dan makin besar, semakin besar pula penggunaan hutang, karena kreditor dan perusahaan itu sendiri beranggapan bahwa semakin besar perusahaan, semakin kecil risiko gagal bayar terhadap hutang. Hasil ini sesuai dengan prediksi dari Trade Off Theory yang menyatakan bahwa hutang dan ukuran perusahaan seharusnya berkorelasi positif (Frank \& Goyal, 2008).

Tabel 7. Hasil Regresi (Perusahaan FDD)

\begin{tabular}{lllll}
\hline Peubah Gayut & Peubah Ingayut & Koefisien & P.Value & Pengaruh \\
\hline STD_FDD & STD_IT & 0.420426 & 0.0588 & Signifikan \\
& Colas & 0.185473 & 0.2959 & Tidak Signifikan \\
& Growth & 0.010272 & 0.0070 & Signifikan \\
& CF_TA & 0.159225 & 0.4009 & Tidak Signifikan \\
& Size & -0.038799 & 0.5544 & Tidak Signifikan \\
\hline
\end{tabular}

Sumber : Data Proses

Pada model hutang jangka pendek pada perusahaan yang berada di bawah tekanan finansial $(F D D)$, peubah hutang jangka pendek periode sebelumnya (STD_IT) adalah peubah bebas yang berpengaruh pada hutang jangka pendek periode saat ini. Tingkat siginifikansi sebesar 5\%, peubah STD_IT memililki probabilitas sebesar 0.0588. STD_IT adalah peubah yang memiliki pengaruh yang siginifikan pada STD periode sekarang, maka ada kecepatan proses penyesuaian terhadap hutang jangka pendek periode saat ini. Besarnya kecepatan penyesuaian yang ada adalah sebesar 57,9574\%. Dapat dikatakan, kecepatan penyesuaian hutang perusahaan kecil di Indonesia ketika sedang mengalami tekanan finansial adalah sebesar $57,9574 \%$. STD_IT juga berkorelasi positif terhadap hutang jangka pendek periode sekarang dengan nilai koefisien sebesar 0.420426 .

Peubah jaminan (Colas) pada penelitian kali ini tidak berpengaruh pada hutang jangka pendek perusahaan kecil di Indonesia yang sedang mengalami tekanan finansial. Nilai dari peubah jaminan didapat dari hasil penjumlahan inventori dan piutang dibagi aset total, yang mana peubah ini tidak menjadi pertimbangan perusahaan kecil dan kreditor dalam pemilihan struktur permodalan untuk hutang jangka pendek. Seberapa bagusnya nilai jaminan dari perusahaan, kreditor dan perusahaan itu sendiri tidak akan melihat aset jaminan sebagai faktor utama dalam pemilihan hutang jangka pendek.

Peubah tingkat pertumbuhan (Growth) memiliki pengaruh yang siginifikan pada perusahaan yang berada di bawah tekanan finasial, dengan pengaruh sebesar 0.010272 dan nilai P sebesar 0.0070. Hasil ini sesuai dengan teori pecking order yang menyatakan bahwa perusahaan yang sedang bertumbuh seharusnya memiliki hutang yang lebih banyak. Hal ini sesuai dengan teori Pecking order yang menyatakan tingkat pertumbuhan dan hutang memiliki hubungan yang positif. Perusahaan yang sedang mengalami tekanan finasial bukan berarti perusahaan tersebut tidak sedang mengalami pertumbuhan. Perusahaan dikatakan mengalami tekanan finasial jika EBIT < Beban Bunga , sehingga, perusahaan yang sedang mengalami tekanan 
finansial juga bisa diindikasikan sedang mengalami pertumbuhan.

Peubah arus kas pada perusahaan kecil yang sedang mengalami tekanan finansial di Indonesia tidak berpengaruh terhadap hutang jangka pendek. Peubah ini didapat dari penjumlahan EBIT dan biaya depresiasi dibagi aset total. Pada perusahaan kecil di Indonesia arus kas tidak memiliki pengaruh pada hutang jangka pendek, karena perusahaan kecil di Indonesia memiliki suatu karakteristik yang lebih konservatif dimana apabila perusahaan tersebut telah memiliki suatu tingkat arus kas yang dinilai cukup untuk kegiatan operasional dan kebutuhan ekspansinya, mayoritas perusahaan tersebut cenderung untuk tidak mengambil hutang atau menambah jumlah hutang terutama hutang jangka pendek dimana jumlah peminjaman ini dinilai mempertinggi risiko bagi pemilik perusahaan tersebut.

Ukuran perusahaan pada perusahaan yang berada di bawah tekanan finansial tidak memiliki pengaruh siginifikan terhadap hutang jangka pendek. Hasil ini didukung oleh teori pecking order yang memprediksikan bahwa ukuran perusahaan dan hutang itu berkorelasi negatif dengan argumen bahwa perusahaan besar ketika menghadapi adverse selection dapat dengan mudah mengeluarkan ekuitas mereka dibandingkan dengan perusahaan kecil. Hasil ini sesuai dengan teori pecking order yang menunjukan adanya koefisien negatif yaitu -0.038799 pada peubah ukuran perusahan (Size) pada perusahaan kecil yang sedang mengalami tekanan finansial.

Kecepatan penyesuaian hutang pada perusahaan dengan kondisi stabil di Indonesia lebih rendah dari pada perusahaan yang berada di bawah tekanan finansial. Secara garis besar, hasil ini didukung oleh definisi dari Myers (1984) yang menyatakan bahwa suatu perusahaan memiliki perilaku penyesuaian target dimana setiap perusahaan memiliki tingkat target hutang di setiap waktu.

Walaupun peubah tingkat pertumbuhan (Growth) pada perusahaan dengan kondisi di bawah tekanan finansial $(F D D)$ dan kondisi stabil (Non FDD) di Indonesia sama-sama memiliki pengaruh yang signifikan, tetapi tingkat pertumbuhan (Growth) pada perusahaan Non FDD memiliki pengaruh yang lebih besar terhadap hutang jangka pendek yang dapat dilihat dari nilai koefisien sebesar 0.035453 , sedangkan koefisien tingkat pertumbuhan (Growth) pada perusahan Non FDD sebesar 0.010272 .

Arus kasper aset total pada perusahaan FDD dan Non FDD tidak memiliki pengaruh yang signifikan terhadap hutang jangka pendek. Hal ini dikarenakan sifat dari perusahaan kecil di Indonesia yang lebih memilih untuk menggunakan dana internal perusahaan dalam pembiyaan finansial dan strukur permodalan jika dirasa arus kas mencukupi, baik itu dalam kondisi stabil maupun dalam kondisi dibawah tekanan finansial. Hasil regresi yang telah dilakukan dengan menggunakan Fixed Effect model, arus kas $\left(C F_{-} T A\right)$ pada perusahaan stabil tidak berpengaruh dan juga berkorelasi negatif dengan hutang jangka pendek sebesar -0.015788. Hal ini sesuai dengan asumsi yang telah dipaparkan sebelumnya, bahwa perusahan kecil dalam kondisi arus kas yang baik, tidak akan melakukan penggunaan hutang. Semakin baik arus kas, semakin sedikit penggunaan hutang dari perusahaan kecil Non FDD tersebut.

Hasil regresi yang didapat dari perusahaan dengan tekanan finansial dengan menggunakan random effect model, arus kas (CF_TA) tidak berpengaruh signifikan pada hutang jangka pendek, tetapi dilihat dari nilai koefisien sebesar 0.159225 memiliki korelasi positif dengan hutang jangka pendek. Hasil ini juga didukung oleh asumsi yang sama dengan perusahaan stabil, yang menyatakan perusahaan kecil dalam kondisi apapun tetap lebih mengutamakan untuk penggunaan dana internal dari pada penggunaan dana ekternal, namun pada perusahaan yang mengalami tekanan finansial tidak menutup kemungkinan untuk melakukan penggunaan hutang ketika arus kas masih dirasa cukup, dengan asumsi perusahaan FDD tidak hanya berjuang untuk bertahan, namun juga berjuang untuk bertahan dan terus bertumbuh, sehingga tidak menutup kemungkinan untuk menggunakan dana eksternal dalam upaya untuk bertahan dan bertumbuh dalam 
kondisi berada pada tekanan finansial, walaupun pada penelitian kali ini, peubah arus kas tidak berpengaruh terhadap hutang jangka pendek perusahaan FDD di Indonesia.

Ukuran perusahaan pada perusahaan kecil Non FDD di Indonesia memiliki pengaruh signifikan dan berkorelasi positif terhadap hutang jangka pendek, namun hasil yang berbeda ditunjukan pada perusahaan kecil yang berada di bawah tekanan finansial di Indonesia yang mana peubah ukuran perusahaan tidak berpengaruh signifikan dan berkorelasi negatif terhadap hutang jangka pendek. Hasil yang berbeda tersebut dapat terjadi karena kondisi perusahaan yang berbeda pula, dimana kelompok perusahaan Non FDD memiliki potensi yang besar untuk terus bertumbuh ke arah ukuran perusahaan yang semakin besar, sehingga dalam kondisi yang stabil, mereka semakin menunjukan keberanian untuk melakukan penggunaan dana eksternal karena perusahaan tersebut dan kreditor melihat kapabilitas untuk membayar hutang yang semakin baik dan risiko gagal bayar yang semakin kecil. Dilain pihak, perusahaan kecil dengan kondisi berada pada tekanan finansial, ketika mereka berusaha untuk bertumbuh, kreditor dan perusahaan itu sendiri berusaha untuk meminimalkan hutang, karena jika perusahaan tersebut tetap melakukan penggunaan dana eksternal dalam upaya untuk memperbesar ukuran perusahaan, maka potensi gagal bayar semakin tinggi. Dari perspektif kreditor, yang pada umumnya adalah bank yang memberikan pinjaman, bank akan berusaha menghindari pembiayaan terhadap perusahaan kecil yang sedang bertumbuh dan berada di bawah tekanan finansial dikarenakan potensi gagal bayar yang tinggi dan juga kapabilitas perusahaan tersebut yang rendah. Dilihat dari hasil penelitian ini, bahwa peubah ukuran perusahaan dan hutang jangka pendek pada perusahaan yang berada di bawah tekanan finansial tidak berpengaruh signifikan dan memiliki korelasi negatif.

\section{SIMPULAN DAN SARAN}

Penelitian ini bertujuan untuk mengetahui faktor-faktor yang berpengaruh pada hutang khususnya hutang jangka pendek pada perusahaan kecil di Indonesia dan juga mengetahui dampak dari adanya tekanan finasial terhadap struktur finansial khususnya hutang jangka pendek pada perusahaan kecil.

Berdasarkan hasil penelitian dan pembahasan, maka dapat diambil kesimpulan sebagai berikut :

1. hutang jangka pendek periode sebelumnya memengaruhi secara signifikan dan memiliki keterhubungan yang positif dengan hutang jangka pendek periode saat ini pada perusahaan FDD dan Non FDD di Indonesia

2. Tingkat pertumbuhan memengaruhi secara signifikan dan memiliki keterhubungan positif terhadap hutang jangka pendek (STD) pada perusahaan dibawah tekanan finansial dan perusahaan stabil di Indonesia

3. Terdapat adanya pengaruh signifikan dan keterhubungan negatif antara ukuran perusahaan dan hutang jangka pendek pada perusahaan dengan kondisi stabil di Indonesia.

Adapun keterbatasan - keterbatasan pada penelitian ini yang membuka ruang bagi penelitian selanjutnya adalah :

1. Peubah bebas yang dipakai hanya terbatas pada hutang jangka pendek periode sebelumnya, aset jaminan, tingkat pertumbuhan, arus kas, dan ukuran perusahaan. Untuk penelitian selanjutnya diharapkan agar dapat memperkenalkan peubah lainnya seperti Non Debt Tax Shield dan Financial Insolvency Cost.

2. Peubah gayut yang diteliti pada penelitian kali ini hanya terbatas pada hutang jangka pendek karena keterbatasan akses data, oleh karena itu, pada penelitian selanjutnya diharapkan adanya tambahan peubah gayut lainnya seperti hutang jangka panjang dan hutang total.

3. Jumlah perusahaan yang diteliti pada penelitian kali ini berjumlah 99 perusahaan kecil dengan nilai penjualan di bawah Rp 150 Milyar 
dalam satu tahun dikarenakan keterbatasan akses data. Pada penelitian berikutnya, diharapkan dapat memperoleh data laporan keuangan perusahaan kecil dengan jangka waktu lebih dari empat tahun dan jumlah perusahaan lebih dari 99 perusahaan.

\section{APPENDIX}

Hutang Jangka Pendek Ratio :

$\mathrm{STD}_{\mathrm{it}}=\mathrm{BVSTD}_{\mathrm{it}} / \mathrm{BVSTD}_{\mathrm{it}}+\mathrm{BVE}_{\mathrm{it}}$,

dimana BVSTD $_{\text {it }}$ adalah book value of Hutang Jangka Pendek.

Collateralisable Assets,

$\operatorname{COLLAS}_{\mathrm{it}}=\left(\mathrm{BI}_{\mathrm{it}}+\mathrm{AR}_{\mathrm{it}}\right) / \mathrm{TA}_{\mathrm{it}}$

Growth Rate,

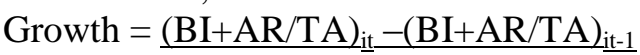

$(\mathrm{BI}+\mathrm{AR} / \mathrm{TA})_{\mathrm{it}-1}$

Dimana BI adalah Inventori, TA adalah

Total Asset dan AR adalah Account

Receivable atau Piutang.

Cash Flow, $\mathrm{CF}_{\text {it }}=\mathrm{EBIT}_{\text {it }}+\mathrm{D}_{\text {it }}$

Yang mana $\mathrm{D}_{\mathrm{it}}$ adalah biaya depresiasi

Size $=\log \left(\mathrm{TA}_{\mathrm{it}}\right)$

\section{DAFTAR PUSTAKA}

Bigelli, Marco, Juan Francisco Martin"Ugedo dan F.Javier Sanchez-Vidal. 2014. Financial Conservatism of Private Firms. Journal of Business Research.: 1-9.

Brooks, Chris. 2008. Introductory econometrics for finance. Cambrige University Press, New York.
Gitman, Lawrence J. 2006. Principles of Managerial Finance, 7th Ed. Pearson Education Inc, Amerika Serikat.

Modigliani F. dan Miller M. 1958. The Cost of Capital, Corporate Finance and the Theory of Investment. American Economic Review 48, No.3: 261-297.

Modigliani F. dan Miller M. 1963. Corporate Income Taxes and The Cost of Capital: A Correction. American Economic Review 53, No. 3: 433-443.

Pindado, Julio, Luis Rodrigues dan Chebela de La Torre. 2006. How Does Financial Distress Affect Small Firm's Financial Structure? Small Business Economics Vol.26, No. 4 pp. 377-391.

Ross, Stephen A. Et all. 2007. Core Principles and Applications of Corporate Finance. McGraww-Hill Companies Inc, New York.

Scarborough, Norman dan Thomas W.Zimemerer. 1993. Effective Small Business Management, 4th Ed. Macmillan Publishing Company, New York.

Shyam-Sunder L. dan Myres C.S. 1999. Testing Trade-off against Pecking Order Models of Capital Structure. Journal of Finance Economics 51: 219244.

Storey, D.J. 2000. Small Business Critical Perspective on Business and Management. NY: Routledge, New York. 